\title{
Soil Invertebrates in Different Land Use Systems: How Integrated Production Systems and Seasonality Affect Soil Mesofauna Communities
}

\author{
Maurício Rumenos Guidetti Zagatto ${ }^{1}$, Cíntia Carla Niva ${ }^{2}$, Marcílio José Thomazini ${ }^{3}$, Dilmar Baretta ${ }^{4}$, Alessandra \\ Santos $^{5}$, Herlon Nadolny ${ }^{5}$, Guilherme Borges Xarão Cardoso ${ }^{5}$ and George Gardner Brown ${ }^{3}$ \\ 1. Luiz de Queiroz College of Agriculture, Universidade de São Paulo (USP), CEP 13418-260 Piracicaba, São Paulo, Brazil \\ 2. Embrapa Cerrados, CEP 73301-970 Planaltina, Distrito Federal, Brazil \\ 3. Embrapa Florestas, CEP 83411-000 Colombo, PR, Brazil \\ 4. Universidade do Estado de Santa Catarina, CEP 89815-630 Chapecó, SC, Brazil \\ 5. Agricultural Sector, Universidade Federal do Paraná, CEP 80035-050 Curitiba, PR, Brazil
}

\begin{abstract}
The soil mesofauna plays a role in organic matter comminution and decomposition, and can be used as bioindicators, since they are sensitive to soil management, vegetation and climate changes. Hence, this study aimed to evaluate mesofauna density and diversity in different land use systems to identify faunal relationships with soil properties, management and seasonality. The study area included five land use systems in Ponta Grossa municipality, Paraná State: integrated crop-livestock (ICL), integrated crop-livestock-forestry (ICLF), grazed native pasture (NP), Eucalyptus dunnii plantation (EU) and no-tillage (NT) cropping systems. In each system, eight soil samples for mesofauna were collected with Berlese funnels of $8 \mathrm{~cm}$ diameter along a transect in three replicate plots of $50 \mathrm{~m} \times 100 \mathrm{~m}$. For physical and chemical analysis, soil was sampled at five points per plot in two seasons: winter 2012 and autumn 2013. Data were statistically analyzed using ANOVA and Duncan's test $(P<0.05)$, nonparametric statistics (when necessary) and redundancy analysis (RDA). Diversity was calculated based on the group richness and Simpson index. The main mesofauna groups found were: Acarina, Collembola and Hymenoptera. Diplopoda, Enchytraeidae, Isopoda, Collembola, Hemiptera, Hymenoptera and Coleoptera larvae were more abundant in autumn than winter. Soil moisture was the main factor responsible for higher mesofauna abundance in autumn. Integrated production systems, especially ICLF had similar invertebrate community abundance and composition with EU, while NT favored Oribatid mites, although the use of insecticides, herbicides and fungicides reduced total mesofauna density. Most correlations between mesofauna and physical-chemical attributes in the winter were not observed in the autumn and vice versa, revealing that there are more factors involved in regulating soil mesofauna distribution.
\end{abstract}

Key words: Soil invertebrates, biodiversity, soil management, bioindicators, seasonality, moisture.

\section{Introduction}

Soil quality reflects the soil's capacity to sustain plant and animal productivity, and maintain or improve quality of water and air which benefit human health [1]. Soil degradation in locations with intensive agriculture decreases soil quality, particularly when the soil is submitted to excessive disturbance, use of external chemical inputs, monocultures and little use of organic inputs [2].

Corresponding author: Maurício Rumenos Guidetti Zagatto, Ph.D. student, research field: soil biology.
Various soil components or processes that reflect soil function can be used as an indicator of soil quality $[3,4]$. The abundance and diversity of soil fauna are considered as soil quality bioindicators, since they are very sensitive to soil management and seasonal variations. Furthermore, soil invertebrates can also contribute to soil porosity, interact with other organisms (e.g., symbiosis, predation) and play an important role in the decomposition of organic matter and nutrient cycling in soils [5-7].

The soil mesofauna comprises small invertebrates, 
such as, mites, springtails, millipedes, spiders, pseudoscorpions and several orders of insects, oligochaetes and crustaceans that have body diameter between $0.2 \mathrm{~mm}$ and $2 \mathrm{~mm}$ [7]. In most soils, springtails and oribatid mites are the main mesofauna groups, and often these groups are the most dominant and diverse in the environment [8]. However, in agricultural systems, mesofauna abundance and richness are often smaller than that in natural systems $[5,9]$ due to soil disturbance, lower levels of organic matter and reduction of available niches [10].

Integrated production systems, such as integrated crop-livestock (ICL) and integrated crop-livestock-forestry (ICLF) are management alternatives to maintain and even increase productivity with greater rationality [11]. Crop rotation and straw accumulation on the soil surface provided by cover crops or pasture in no-tillage (NT) systems provide an environment for recovery or maintenance of soil physical, chemical and biological quality [12].

Studies involving soil mesofauna populations in Brazilian agroecosystems are still scarce, although higher abundance and diversity of soil invertebrates have been reported in ICL and NT systems compared with conventional tillage systems, since conservationist systems promote higher soil fertility and aggregate stability than conventional systems where the soil is frequently plowed [13].

Therefore, the present study aimed to evaluate the use of soil mesofauna as soil quality indicators, by comparing the density and diversity of soil mesofauna and their relation with seasonality, soil management and soil properties in agricultural systems with and without trees in the Brazilian sub-tropics.

\section{Materials and Methods}

\subsection{Study Site}

The study site is located in Ponta Grossa county, Paraná State, Brazil (ICL and ICLF were in $25^{\circ} 05^{\prime} 11^{\prime \prime} \mathrm{S}$ and $50^{\circ} 04^{\prime} \mathrm{W}$, while native pasture (NP) and $E$. dunnii plantation (EU) were in $25^{\circ} 08^{\prime} \mathrm{S}$ and $\left.50^{\circ} 9^{\prime} 38^{\prime \prime} \mathrm{W}\right)$, at approximately $875 \mathrm{~m}$ elevation. The climate is $\mathrm{Cfb}$ according to the Köeppen classification, with average annual temperature below $21^{\circ} \mathrm{C}$ (frequently between $9{ }^{\circ} \mathrm{C}$ and $23{ }^{\circ} \mathrm{C}$ ), with no distinct dry season and with mean annual rainfall from $1,300 \mathrm{~mm}$ to $1,800 \mathrm{~mm}$ [14], however the rainy season in the sampling period occurred during the autumn.

Five land use systems were evaluated in this study: (1) a 7-year old ICLF system with rows of Eucalyptus dunnii; (2) a 7-year old ICL system; (3) a > 30 years old NP system; (4) a 30-yeat old NT agriculture system; (5) a 20-year old EU system (Table 1). In each system, three $100 \mathrm{~m} \times 100 \mathrm{~m}$ plots were selected and samples were taken.

In the autumn, integrated systems were cultivated with soybeans (Glycine max (L.) Merr.) and no-tillage with common beans (Phaseolus vulgaris), while in winter these systems were cultivated with oats (Avena strigosa) (Table 1).

The NT field received $205 \mathrm{~kg} / \mathrm{ha}$ mono-ammonium phosphate, $185 \mathrm{~kg} / \mathrm{ha}$ urea, $150 \mathrm{~kg} / \mathrm{ha} \mathrm{KCl}$ and 1.61 $\mathrm{L} /$ ha foliar manganese, while ICL and ICLF received $220 \mathrm{~kg} / \mathrm{haNPK}$ (4:30:10) and $200 \mathrm{~kg} / \mathrm{ha}$ of $\mathrm{N}$ as urea when cultivated with oats, rye grass and maize. When these systems were cultivated with soybeans, $72 \mathrm{~kg} / \mathrm{ha}$ $\mathrm{P}_{2} \mathrm{O}_{5}$ and $240 \mathrm{~kg} / \mathrm{ha}$ of $\mathrm{K}_{2} \mathrm{O}$ were applied at sowing and $42 \mathrm{~kg} / \mathrm{ha} \mathrm{K}_{2} \mathrm{O}$ in the form of potassium chloride at $23 \mathrm{~d}$ after planting.

\subsection{Soil Analysis}

Soil samples were taken in parallel to mesofauna samples for moisture measurement by gravimetric methods in autumn and winter. Five soil samples were taken at depths $0-10 \mathrm{~cm}$ in October 2012 in each plot for chemical and particle size analysis according to EMBRAPA [15]. These samples were sieved (2 mm mesh) and homogenized for subsequent determination of the following chemical attributes: $\mathrm{pH}$ in $\mathrm{CaCl}_{2}, \mathrm{P}$ (extraction with Mehlich-1), $\mathrm{K}$ and $\mathrm{Na}$ (extraction with dilute $\mathrm{HCl}$ ), $\mathrm{Ca}, \mathrm{Mg}$ and $\mathrm{Al}$ (extraction with $1 \mathrm{~N}$ 
Table 1 Characteristics of five land use systems in the studied sites.

\begin{tabular}{llll}
\hline Land use systems & Age (years) & Cultivated crops & Soil \\
\hline ICL and ICLF & 7 & $\begin{array}{l}\text { Winter: Avena strigosa and Lolium multiflorum grazed by Puruna cattle; } \\
\text { Summer: corn or soybeans in biennial rotation systems. }\end{array}$ & $\begin{array}{l}\text { Rhodic ferralsol + haplic } \\
\text { cambisol }\end{array}$ \\
\hline NP & $>30$ & Native vegetations. & $\begin{array}{l}\text { Rhodic ferralsol + haplic } \\
\text { cambisol }\end{array}$ \\
\hline EU & 20 & E. dunnii plantation since 1983. & Rhodic ferralsol \\
\hline NT & 30 & $\begin{array}{l}\text { Wheat-soy/oats-corn/oats-beans; } \\
\text { When cultivated with beans, insecticides (Azadirachtin-A), fungicides } \\
\text { (Azoxystrobin, Difenoconazole and Carbendazim) and herbicides } \\
(2,4-D, \text { Fomesafen, Bentazona and Cletodim) applied. }\end{array}$ & Rhodic ferralsol \\
\hline
\end{tabular}

$\mathrm{KCl}$ ) and potential acidity $\mathrm{H}+\mathrm{Al}$ (extraction with calcium acetate). The sand, silt and clay were separated by the total dispersion method. In this method, a chemical dispersant and water are added to the soil for subsequent obtaining of coarse fractions by sieving, while the clay is obtained by pipetting and the silt is obtained by difference of the other fractions in relation to the original sample.

The total organic carbon and nitrogen were determined by wet oxidation of the organic matter [16].

\subsection{Soil Mesofauna Analysis}

In each plot, eight soil samples were taken with Berlese funnels $(8 \mathrm{~cm}$ diameter $\times 5 \mathrm{~cm}$ depth) distanced at least $15 \mathrm{~m}$ apart, arranged in two parallel transects with $80 \mathrm{~m}$, distant $30 \mathrm{~m}$ apart. In total, 120 samples were taken in winter $(08 / 2012)$ and 120 samples were taken in the autumn (04/2013).

The invertebrates were separated and identified at the order level under a stereoscopic microscope. All mesofauna abundance data were extrapolated to the number of individuals $/ \mathrm{m}^{2}$ based on the funnel area.

Diversity was calculated using richness (total and mean number of groups per system and the mean number of groups per sample), and Simpson index (SI) was calculated by Eq. (1):

$$
S I=1-D=1-\Sigma p i^{2}
$$

where, $D$ represents the dominance expressed by $\Sigma p i^{2}$, and $p i$ is the relative abundance of each taxonomic group sampled [17].

\subsection{Statistical Analysis}

The collected data were analyzed by using analysis of variance to compare the effects of different land use systems on the soil chemical, physical and biological attributes (mesofauna groups). The Duncan's test at 5\% of significance was used to separate the parameters between the different land use systems and sampling date (winter vs. autumn). When data could not be normalized and/or variances were not homogeneous, the nonparametric Kruskal-Wallis test were performed. Regression analyses were performed between soil moisture and groups of soil mesofauna to verify the influence of seasonality on soil invertebrates. Person's correlation and regression analyses were performed to verify significant correlations between soil mesofauna and soil attributes. All tests were conducted using the software Statistica version 7.

Average mesofauna abundance sampled in winter and in autumn separately from the three plots and soil analysis results were used in a redundancy analysis (RDA) to establish relationships between mesofauna, soil physical and chemical attributes and management. Orders that accounted for less than $5 \%$ of the total abundance in one of the studied seasons were combined in a category named "others". To test the significance of the RDA, the Monte Carlo test was performed. These analysis were made using the software Canoco for Windows version 4.5 [18].

\section{Results and Discussion}

\subsection{Soil Analysis}

The soils in the study areas are acid and present low 

Systems and Seasonality Affect Soil Mesofauna Communities

natural fertility and low organic matter content, due to relatively high sand and low clay contents (Table 2). The parent material in the region is sedimentary rocks; in a remote past, the region was a sea bottom [19].

NP and EU systems had lower exchangeable cations and high potential acidity, while ICLF and NT systems had lower $\mathrm{C} / \mathrm{N}$ ratio. Statistically significant differences were observed in relation to the carbon content in these land uses, and ICLF had lower soil $\mathrm{C}$ compared to NP and EU systems. ICL, ICLF and NT systems had higher $\mathrm{pH}$, base saturation and $\mathrm{P}$ contents (Table 2), because these systems are often fertilized.

Soil moisture contents did not differ between the land use systems, although it was generally higher in autumn than that in winter (Fig. 1), due to higher autumn rainfall.

\subsection{Effect of Seasonality on Soil Mesofauna}

Some mesofauna groups were strongly influenced by seasonality. Those mesofauna groups with higher population densities in autumn than that in winter were: Collembola in NP, EU and NT, Coleoptera larve in ICL and ICLF, Hymenoptera and Hemiptera in NP. Total mesofauna density was higher in ICL and NT in autumn in comparison with winter, as was richness in ICL. Groups, like Dipolopoda, Enchytraeidade and Isopoda, were found only in autumn samples (Table 3).

On one hand, a positive correlation was observed between total mesofauna abundance and Coleoptera larvae with soil moisture content (Fig. 2). Water content in soil is an important regulator of soil life, since most biochemical processes, such as enzymatic activity and reproduction, are very dependent on water [20]. And water promotes higher availability of chemical nutrients in soil solution which favors plant growth, and organic matter inputs to soil which favors detritivorous soil mesofauna [21]. The results in this

Table 2 Chemical and physical attributes of soil in ICL, ICLF, NP, EU and NT systems in 0-10 cm layer in Ponta Grossa, Paraná, Brazil.

\begin{tabular}{|c|c|c|c|c|c|c|}
\hline Unit & Attributes & ICL & ICLF & NP & EU & NT \\
\hline & $\mathrm{pH}\left(\mathrm{CaCl}_{2}\right)$ & $5.00^{\mathrm{a}}$ & $5.17^{\mathrm{a}}$ & $3.81^{\mathrm{c}}$ & $3.71^{\mathrm{c}}$ & $4.48^{\mathrm{b}}$ \\
\hline \multirow{8}{*}{$\mathrm{cmol} / \mathrm{dm}^{3}$} & $\mathrm{Al}$ & $0.07^{\mathrm{b}}$ & $0.007^{\mathrm{b}}$ & $1.03^{\mathrm{a}}$ & $1.95^{\mathrm{a}}$ & $0.19^{\mathrm{b}}$ \\
\hline & $\mathrm{H}+\mathrm{Al}$ & $3.12^{\mathrm{c}}$ & $2.93^{c}$ & $7.10^{\mathrm{a}}$ & $8.04^{\mathrm{a}}$ & $5.05^{\mathrm{b}}$ \\
\hline & $\mathrm{Ca}$ & $3.50^{\mathrm{a}}$ & $3.03^{\mathrm{a}}$ & $0.80^{\mathrm{b}}$ & $0.10^{\mathrm{b}}$ & $3.14^{\mathrm{a}}$ \\
\hline & $\mathrm{Mg}$ & $1.47^{\mathrm{a}}$ & $1.10^{\mathrm{a}}$ & $0.53^{\mathrm{b}}$ & $0.14^{\mathrm{b}}$ & $1.12^{\mathrm{a}}$ \\
\hline & $\mathrm{K}$ & $0.24^{\mathrm{b}}$ & $0.20^{\mathrm{b}}$ & $0.13^{\mathrm{c}}$ & $0.06^{\mathrm{d}}$ & $0.40^{\mathrm{a}}$ \\
\hline & $\mathrm{Na}$ & $0.01^{\mathrm{b}}$ & $0.01^{\mathrm{b}}$ & $0.01^{\mathrm{b}}$ & $0.02^{\mathrm{a}}$ & $0.01^{\mathrm{b}}$ \\
\hline & SB & $5.21^{\mathrm{a}}$ & $4.35^{\mathrm{a}}$ & $1.46^{\mathrm{b}}$ & $0.32^{\mathrm{b}}$ & $4.67^{\mathrm{a}}$ \\
\hline & CEC & $8.33^{\mathrm{ab}}$ & $7.28^{\mathrm{b}}$ & $8.57^{\mathrm{ab}}$ & $8.36^{\mathrm{ab}}$ & $9.71^{\mathrm{a}}$ \\
\hline \multirow{2}{*}{$\%$} & $\mathrm{~V}$ & $62.20^{\mathrm{a}}$ & $59.32^{\mathrm{a}}$ & $15.88^{\mathrm{c}}$ & $4.11^{\mathrm{d}}$ & $47.92^{\mathrm{b}}$ \\
\hline & $\mathrm{m}$ & $0.82^{\mathrm{bc}}$ & $0.09^{c}$ & $12.64^{\mathrm{a}}$ & $25.94^{\mathrm{a}}$ & $2.15^{\mathrm{b}}$ \\
\hline \multirow{3}{*}{$\mathrm{g} / \mathrm{dm}^{3}$} & $\mathrm{C}$ & $12.41^{\mathrm{ab}}$ & $10.37^{\mathrm{b}}$ & $15.03^{\mathrm{a}}$ & $16.60^{\mathrm{a}}$ & $14.47^{\mathrm{ab}}$ \\
\hline & $\mathrm{N}$ & $0.61^{\mathrm{b}}$ & $0.59^{\mathrm{b}}$ & $0.80^{\mathrm{ab}}$ & $0.75^{\mathrm{ab}}$ & $1.03^{\mathrm{a}}$ \\
\hline & $\mathrm{C} / \mathrm{N}$ & $22.06^{\mathrm{a}}$ & $17.84^{\mathrm{b}}$ & $18.98^{\mathrm{ab}}$ & $22.10^{\mathrm{a}}$ & $14.14^{\mathrm{c}}$ \\
\hline ppm & $\mathrm{P}$ & $25.51^{b}$ & $35.57^{\mathrm{ab}}$ & $3.73^{\mathrm{c}}$ & $2.27^{\mathrm{c}}$ & $45.99^{\mathrm{a}}$ \\
\hline \multirow{3}{*}{$\mathrm{g} / \mathrm{kg}$} & Sand & $715.80^{\mathrm{ab}}$ & $740.47^{\mathrm{a}}$ & $720.80^{\mathrm{a}}$ & $676.90^{\mathrm{bc}}$ & $646.33^{c}$ \\
\hline & Silt & $210.67^{b}$ & $200.00^{\mathrm{b}}$ & $202.67^{b}$ & $236.00^{\mathrm{ab}}$ & $281.33^{\mathrm{a}}$ \\
\hline & Clay & $73.53^{\mathrm{ab}}$ & $59.53^{\mathrm{b}}$ & $76.53^{\mathrm{ab}}$ & $87.10^{\mathrm{a}}$ & $72.33^{\mathrm{ab}}$ \\
\hline
\end{tabular}

CEC: cation exchange capacity; SB: sum of bases; V\%: saturation of the CEC by basic cations; $\mathrm{m} \%$ : saturation of CEC by aluminum.

Means followed by the same letter on the line do not differ statistically by Duncan's test $(P<0.05)$. 


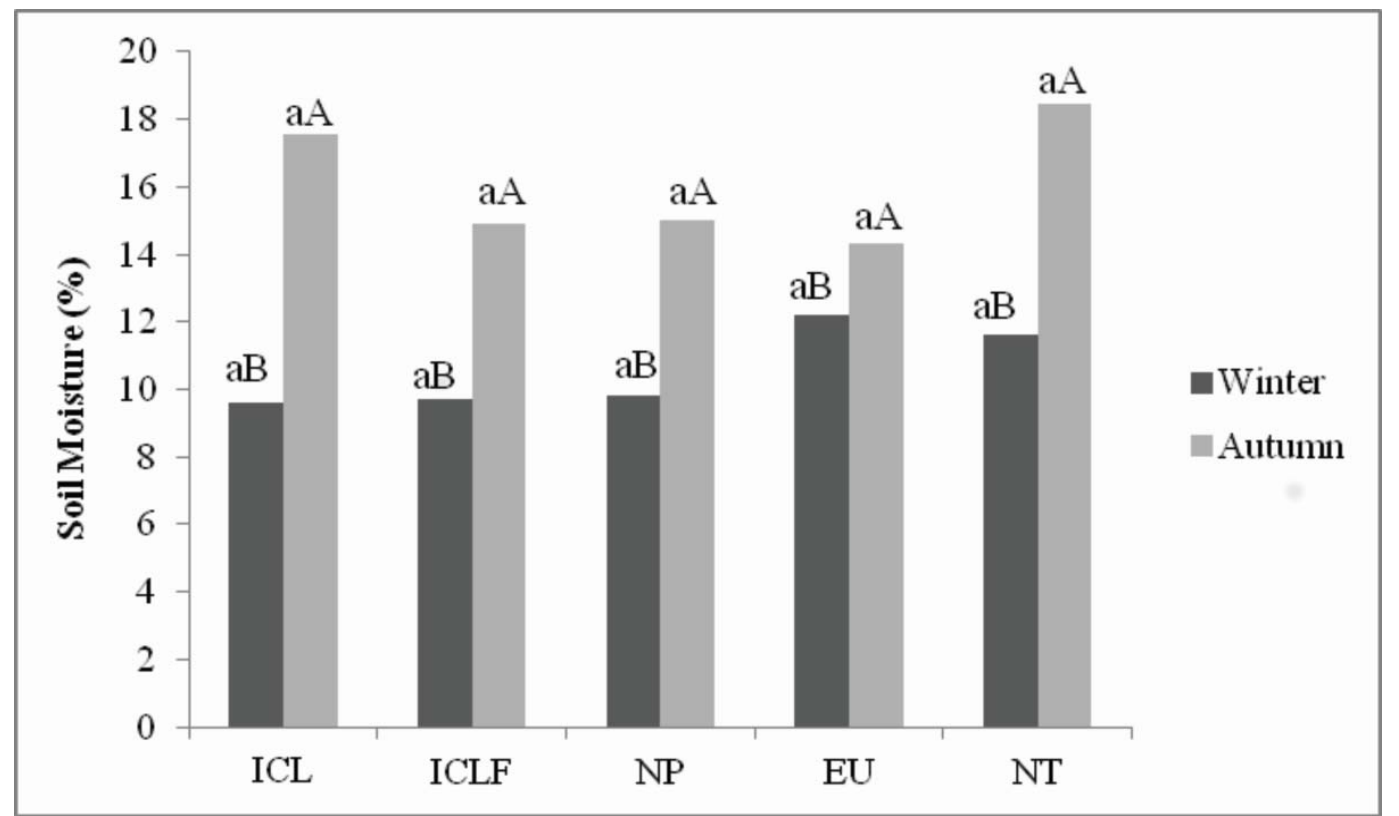

Fig. 1 Soil moisture in winter and autumn in ICL, ICLF, NP, EU and NT systems.

Different capital letters indicate differences between seasons, while different lower case letters indicate differences between land use systems by the Duncan's test $(P<0.05)$.

Table 3 Density (individuals $/ \mathbf{m}^{2}$ ) and diversity of soil mesofauna in different land use systems in Ponta Grossa, PR.

\begin{tabular}{|c|c|c|c|c|c|c|c|c|c|c|}
\hline \multirow{2}{*}{ Groups } & \multicolumn{5}{|c|}{ Winter } & \multicolumn{5}{|c|}{ Autumn } \\
\hline & ICL & ICLF & NP & EU & NT & ICL & ICLF & NP & EU & NT \\
\hline Oribatei mites & $2,014^{\mathrm{b}}$ & $2,104^{\mathrm{c}}$ & $980^{\mathrm{c}}$ & $1,530^{\mathrm{bc}}$ & $10,755^{\mathrm{a}^{*}}$ & $7,996^{\mathrm{a}}$ & $1,988^{\mathrm{ab}}$ & $874^{\mathrm{b}}$ & $3,770^{\mathrm{ab}}$ & $1,529^{b}$ \\
\hline Predators mites & $795^{\mathrm{ab}}$ & $558^{\mathrm{b}}$ & $114^{\mathrm{c}}$ & $1,422^{\mathrm{a}}$ & $781^{\mathrm{ab}^{*}}$ & $2,407^{\mathrm{a}}$ & $641^{\mathrm{b}}$ & $461^{\mathrm{b}}$ & $908^{\mathrm{ab}}$ & $113^{b}$ \\
\hline Total mites & $2,809^{\mathrm{b}}$ & $2,662^{\mathrm{b}}$ & $1,094^{\mathrm{c}}$ & $2,952^{\mathrm{b}}$ & $11,536^{\mathrm{a}^{*}}$ & $10,043^{\mathrm{a}}$ & $2,629^{\mathrm{ab}}$ & $1,335^{\mathrm{b}}$ & $4,678^{\mathrm{ab}}$ & $1,642^{\mathrm{b}}$ \\
\hline Collembola & $795^{\mathrm{ab}}$ & $2,546^{\mathrm{a}}$ & $191^{\mathrm{c}^{*}}$ & $520^{\mathrm{bc}^{*}}$ & $166^{\mathrm{c}^{*}}$ & $1,211^{\mathrm{b}}$ & $365^{\mathrm{c}}$ & $1,261^{\mathrm{ab}}$ & $1,210^{\mathrm{a}}$ & $423^{b}$ \\
\hline Araneae & $43^{\mathrm{a}}$ & $8^{\mathrm{a}}$ & $17^{\mathrm{a}}$ & $55^{\mathrm{a}}$ & $8^{a}$ & $41^{\mathrm{a}}$ & $8^{\mathrm{a}}$ & $16^{\mathrm{a}}$ & $41^{\mathrm{a}}$ & $8^{\mathrm{a}}$ \\
\hline Coleoptera adult & $99^{\mathrm{a}}$ & $91^{\mathrm{a}}$ & $66^{\mathrm{a}}$ & $97^{\mathrm{a}}$ & $91^{\mathrm{a}}$ & $149^{\mathrm{a}}$ & $83^{\mathrm{ab}}$ & $0^{\mathrm{c}}$ & $149^{\mathrm{a}}$ & $25^{\mathrm{bc}}$ \\
\hline Coleoptera larve & $53^{\mathrm{a}^{*}}$ & $41^{\mathrm{a}^{*}}$ & $25^{\mathrm{a}}$ & $8^{\mathrm{a}}$ & $41^{\mathrm{a}}$ & $241^{\mathrm{a}}$ & $107^{\mathrm{ab}}$ & $25^{\mathrm{b}}$ & $241^{\mathrm{b}}$ & $41^{\mathrm{b}}$ \\
\hline Total Coleoptera & $152^{\mathrm{a}}$ & $132^{\mathrm{a}}$ & $91^{\mathrm{a}}$ & $105^{\mathrm{a}}$ & $132^{\mathrm{a}}$ & $390^{\mathrm{a}}$ & $190^{\mathrm{b}}$ & $25^{\mathrm{c}}$ & $350^{\mathrm{b}}$ & $66^{\mathrm{c}}$ \\
\hline Hymenoptera & $91^{\mathrm{b}}$ & $290^{\mathrm{ab}}$ & $423^{\mathrm{a}}$ & $224^{\mathrm{ab}}$ & $83^{\mathrm{ab}^{*}}$ & $547^{\mathrm{ab}}$ & $357^{\mathrm{b}}$ & $9,728^{\mathrm{a}}$ & $547^{\mathrm{ab}}$ & $440^{\mathrm{ab}}$ \\
\hline Diplura & $1^{\mathrm{a}}$ & $8^{a}$ & $8^{\mathrm{a}}$ & $3^{\mathrm{a}}$ & $0^{\mathrm{a}}$ & $0^{\mathrm{a}}$ & $0^{\mathrm{a}}$ & $8^{\mathrm{a}}$ & $0^{\mathrm{a}}$ & $0^{\mathrm{a}}$ \\
\hline Protura & $0^{\mathrm{a}}$ & $17^{\mathrm{a}}$ & $0^{\mathrm{a}}$ & $0^{\mathrm{a}}$ & $0^{\mathrm{a}}$ & $0^{\mathrm{a}}$ & $0^{\mathrm{a}}$ & $2,803^{\mathrm{a}}$ & $0^{\mathrm{a}}$ & $75^{\mathrm{a}}$ \\
\hline Thysanoptera & $35^{\mathrm{a}}$ & $75^{\mathrm{a}}$ & $41^{\mathrm{a}}$ & $55^{\mathrm{a}}$ & $75^{\mathrm{a}}$ & $8^{\mathrm{a}}$ & $8^{\mathrm{a}}$ & $133^{\mathrm{a}}$ & $8^{\mathrm{a}}$ & $58^{\mathrm{a}}$ \\
\hline Hemiptera & $17^{\mathrm{a}}$ & $0^{\mathrm{a}}$ & $149^{\mathrm{a}}$ & $50^{\mathrm{a}}$ & $0^{\mathrm{a}^{*}}$ & $25^{\mathrm{b}}$ & $16^{\mathrm{b}}$ & $108^{\mathrm{a}}$ & $25^{\mathrm{ab}}$ & $83^{\mathrm{ab}}$ \\
\hline Diptera larve & $11^{\mathrm{a}}$ & $8^{\mathrm{a}}$ & $0^{\mathrm{a}}$ & $8^{\mathrm{a}}$ & $33^{\mathrm{a}}$ & $8^{\mathrm{a}}$ & $33^{\mathrm{a}}$ & $0^{\mathrm{a}}$ & $8^{a}$ & $8^{\mathrm{a}}$ \\
\hline Chilopoda & $8^{\mathrm{a}}$ & $0^{\mathrm{a}}$ & $0^{\mathrm{a}}$ & $25^{\mathrm{a}}$ & $0^{\mathrm{a}}$ & $8^{\mathrm{a}}$ & $0^{\mathrm{a}}$ & $0^{\mathrm{a}}$ & $8^{\mathrm{a}}$ & $0^{\mathrm{a}}$ \\
\hline Diplopoda & - & - & - & - & - & $8^{\mathrm{a}}$ & $0^{\mathrm{a}}$ & $0^{\mathrm{a}}$ & $8^{\mathrm{a}}$ & $0^{\mathrm{a}}$ \\
\hline Isopoda & - & - & - & - & - & $0^{\mathrm{a}}$ & $17^{\mathrm{a}}$ & $0^{\mathrm{a}}$ & $0^{\mathrm{a}}$ & $0^{\mathrm{a}}$ \\
\hline Enchytraeidae & - & - & - & - & - & $8^{\mathrm{a}}$ & $0^{\mathrm{a}}$ & $0^{\mathrm{a}}$ & $8^{\mathrm{a}}$ & $17^{\mathrm{a}}$ \\
\hline Blattodea & $2^{\mathrm{a}}$ & $0^{\mathrm{a}}$ & $17^{\mathrm{a}}$ & $6^{\mathrm{a}}$ & $0^{\mathrm{a}}$ & $8^{\mathrm{a}}$ & $8^{\mathrm{a}}$ & $0^{\mathrm{a}}$ & $0^{\mathrm{a}}$ & $0^{\mathrm{a}}$ \\
\hline Total density & $4,010^{\mathrm{b}^{*}}$ & $5,830^{\mathrm{b}}$ & $2,057^{\mathrm{c}}$ & $4,020^{b}$ & $12,050^{\mathrm{a}^{*}}$ & $12,308^{\mathrm{a}}$ & $3,649^{\mathrm{a}}$ & $15,509^{\mathrm{a}}$ & $12,308^{\mathrm{a}}$ & $2,861^{\mathrm{a}}$ \\
\hline Total richness & 7 & 9 & 9 & 8 & 7 & 11 & 10 & 9 & 13 & 10 \\
\hline Mean richness (system) & $5.67^{\mathrm{a}^{*}}$ & $6.33^{\mathrm{a}}$ & $6.33^{\mathrm{a}}$ & $6.00^{\mathrm{a}}$ & $5.33^{\mathrm{a}}$ & $10.00^{\mathrm{a}}$ & $9.00^{\mathrm{a}}$ & $6.33^{\mathrm{a}}$ & $9.00^{\mathrm{a}}$ & $7.33^{\mathrm{a}}$ \\
\hline Richness in per sample & $2.58^{\mathrm{a}}$ & $2.96^{\mathrm{a}}$ & $2.50^{\mathrm{a}}$ & $3.04^{\mathrm{a}}$ & $2.25^{\mathrm{a}}$ & $3.17^{\mathrm{a}}$ & $2.88^{\mathrm{a}}$ & $3.21^{\mathrm{a}}$ & $3.83^{\mathrm{a}}$ & $2.83^{\mathrm{a}}$ \\
\hline Dominance (system) & $0.55^{\mathrm{bc}}$ & $0.48^{\mathrm{c}}$ & $0.38^{\mathrm{d}}$ & $0.64^{\mathrm{b}}$ & $0.91^{\mathrm{a}^{*}}$ & $0.56^{\mathrm{a}}$ & $0.43^{\mathrm{a}}$ & $0.50^{\mathrm{a}}$ & $0.41^{\mathrm{a}}$ & $0.38^{\mathrm{a}}$ \\
\hline Simpson index (system) & $0.45^{\mathrm{bc}}$ & $0.52^{\mathrm{b}}$ & $0.62^{\mathrm{a}}$ & $0.36^{\mathrm{c}^{*}}$ & $0.09^{\mathrm{d}^{*}}$ & $0.44^{\mathrm{a}}$ & $0.57^{\mathrm{a}}$ & $0.50^{\mathrm{a}}$ & $0.59^{\mathrm{a}}$ & $0.62^{\mathrm{a}}$ \\
\hline
\end{tabular}




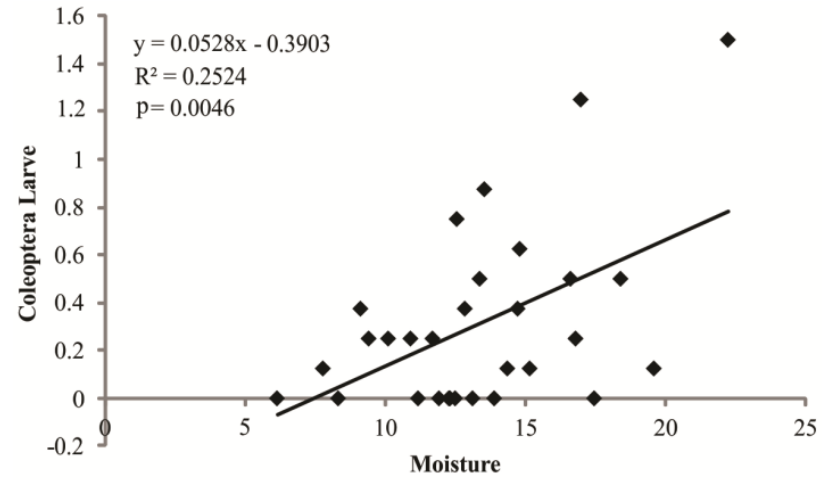

(a)

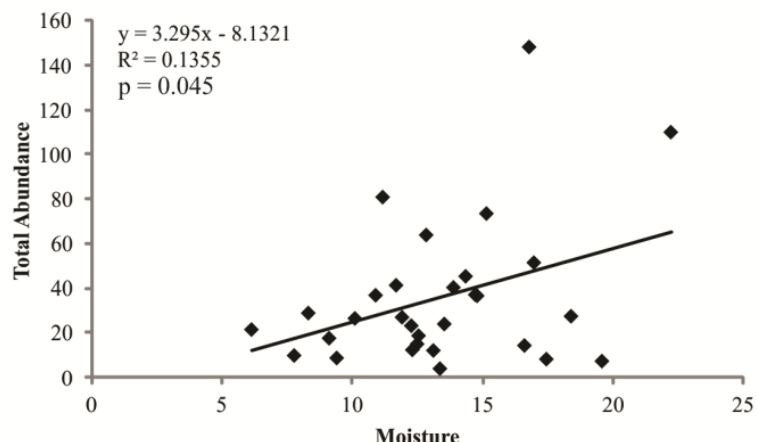

(b)

Fig. 2 Effect of soil moisture on abundance of coleoptera larvae (a) and total mesofauna abundance (b).

study agree with Manhães et al. [22] who found variations due to the seasonality in the population of microbial grazers, micropredators and herbivores in the dry season. Marchão et al. [23] reported that the soil fauna in ICL areas in the Brazilian Cerrado had high abundance of Coleoptera, Oligochaeta and Diplopoda in NT fields with large amounts of litter.

On the other hand, in NT, Acarina density was higher in winter $\left(11,536\right.$ individuals $\left./ \mathrm{m}^{2}\right)$ than that in autumn $\left(1,642\right.$ individuals $\left./ \mathrm{m}^{2}\right)$. This also led to higher total soil mesofauna density in winter in this land use system, as well as higher dominance value and lower Simpson's diversity index, not only comparing sampling dates in NT (winter vs. autumn), but also comparing NT with the other land use systems in the winter (Table 3). Whereas the higher Simpson's diversity and mean richness were observed in EU and ICL, respectively, in autumn than that in winter (Table 3 ), possibly due the higher litter accumulation over the period from one sampling season (winter) to the other (autumn), which promotes the development of complex invertebrate communities [24].

The lower total mesofauna populations in NT in autumn, even with higher soil moisture than that in winter, may be due to the use of insecticides (Azadirachtin-A), fungicides (Azoxystrobin, Difenoconazole and Carbendazim) and herbicides (2,4-D, Fomesafen, Bentazona and Cletodim) when $P$. vulgaris beans were cultivated. Fungicide and herbicide application can have direct and/or indirect impacts on soil fauna, fungicides eliminate fungi that serve as food for many orders of soil fauna and result in the death of many individuals [25]. Herbicides kill weeds, decreasing plant material supply and even the soil rhizosphere, reducing the amount of available niches and food for wildlife, thus resulting in the decrease of many microarthropod populations [26, 27]. Insecticides directly affect arthropods that live in the soil [28] and negative effects can be detected both in the field and in laboratory tests [29].

\subsubsection{Soil Mesofauna in Winter}

There were 12 mesofauna orders identified in winter. Richness in the different systems ranged in 7-9 orders. Average richness did not differ statistically between the systems, but the Simpson index was higher in NP and lower in NT (Table 3). In comparison, Moço et al. [30] found a total of six taxa and 566 individuals/ $\mathrm{m}$ in pastures, and 8-10 taxa and 496 individuals $/ \mathrm{m}^{2}$ in Eucalyptus (Corymbia citriodora), respectively, with a predominance of Hymenoptera in both systems which occurred only in NP in this study. Besides, the abundance of Collembola they found (23 and 15 individuals $/ \mathrm{m}^{2}$ in grassland and Eucalyptus, respectively) was lower than that in the present study. Therefore, this study presented higher diversity and abundance than that in similar studies on soil mesofauna. Diversified ecosystems tend to be more resilient, since a great variety of organisms can perform the same role in the ecosystem, and even if some organisms disappear due an extinction event, the 
ecosystem function is not lost [31].

RDA explained $79.4 \%$ of the data variation in winter, with $46.2 \%$ of the data variation explained by the first two axes. Among these, 89.3\% were explained by the relationship between the mesofauna groups and the physical and chemical soil atributes (Fig. 3a). The Monte Carlo permutation was significant $(P<0.05)$ for the first two axes and for all axes of RDA.

Three represented groups of land use systems could be observed: (1) NP, positively correlated with Simpson diversity, "other" invertebrates (represented by the sum of Protura, Dipera larvae, Heteroptera, Chilopoda, Blattodea and Diplura), Hymenoptera and Aluminum; (2) NT correlated positively with Oribatei mites, CEC, silt, P and V\%; (3) ICL, ICLF and EU correlated positively with richness of sampled groups, Collembola, Coleoptera, predatory mites, Aranae, Thysanoptera, $\mathrm{C} / \mathrm{N}$ ratio and $\mathrm{pH}$ (Fig. 3a). NT formed a cluster mainly due to the great abundance of Oribatei mites (Fig. 1 and Table 1), as these plots have been in this system for 30 years, which may favor the existence of more complex organisms, due to the maintenance of straw residues, crop rotation and lack of soil tillage. On the other hand, the cluster formed by NP is related to lower soil fertility (high $\mathrm{Al}$ contents), and abundance of Hymenoptera and other organisms (Fig. 1). Poorer soils found in degraded pastures often favor the abundance of some invertebrates groups, which in these conditions may even become pests [32, 33].

Axis 1 separated sites on the basis of mesofauna dominance and abundance, while axis 2 separated sites with or without Eucalyptus trees, and was highly correlated with mesofauna richness, collembolan abundance, $\mathrm{CEC}$ and $\mathrm{C} / \mathrm{N}$ ratios. This agrees partially with Rosa et al. [34] who also found higher soil fauna richness in Eucalyptus reforestation than that in ICL and NT areas located in the Santa Catarina plateau. The fine roots of Eucalyptus and the large amount of litter deposited on the surface may favor soil mesofauna richness in EU and integrated systems, since litter represents a direct food source for soil mesofauna [35]. The roots continuously secrete carbon compounds with low molecular weight that serve as food for microorganisms [36], and these could be actively predated by soil mesofauna. Moreover, the increase of organic matter contents and the improvement of soil physical quality by the introduction of the ICLF system with Eucalyptus trees in agricultural areas may provide higher availability of niches in ICLF that will favor a complex and well structured community of soil invertebrates [12,37].

Few significant correlations were observed between soil mesofauna groups and physical-chemical soil attributes in the winter. However, most of the sampled groups were correlated negatively with $\mathrm{C} / \mathrm{N}$ ratios and positively with soil $\mathrm{N}$ contents (Table 4), indicating preference of mesofauna for previously decomposed food resources [7]. In addition, the lower soil moisture was observed in winter than that in the autumn (Fig. 1), and under these conditions, there was not any relationship found between soil moisture and mesofauna groups (Table 4).

\subsubsection{Soil Mesofauna in Autumn}

In autumn, total mesofauna density did not differ between the land use systems due to very high data variability. ICL had higher mite density than NP and NT, while EU had higher Collembola density than ICL, ICLF and NT (Table 3). Cattle dung combined with straw increase $\mathrm{N}$ mineralization in soil [38], which can positively affect Acarina and mesofauna density in grazed systems, such as observed in ICL and ICLF.

It was identified in only two samples of NP that 336 individuals belong to Class Protura and 1,043 individuals belong to the order Hymenoptera, respectively. This high abundance in only two samples in autumn is due to the highly uneven or aggregate distribution of many soil animals, particularly termites and ants that create nests $[33,39]$. Protura is a class of edaphic invertebrates associated 

Systems and Seasonality Affect Soil Mesofauna Communities

with decomposing organic matter and high moisture, and can be found in mosses and lichens on the soil surface [40]. Moreover, their occurrence may also depend on mycorrhizal fungi [41].

RDA explained $71.4 \%$ of the data variation in autumn, with $56.5 \%$ of data variation explained by the first two axes. Among these, $93.1 \%$ were explained by the relationship between the mesofauna groups and the physical and chemical soil atributes. Axis 1 separated sites with high abundance of soil mesofauna (especially EU and ICL), particularly Acari and Collembola from sites with fewer individuals. Axis 2 separated agricultural sites with higher $\mathrm{pH}$ and $\mathrm{P}$ contents from $\mathrm{EU}$ and $\mathrm{NP}$, with higher $\mathrm{C}$ and $\mathrm{Al}$ contents (Fig. 3b). The Monte Carlo permutation was significant $(P<0.05)$ for the first two axes and for all axes of RDA.

Four clusters were observed: (1) NT associated with low total fauna abundance; (2) NP correlated

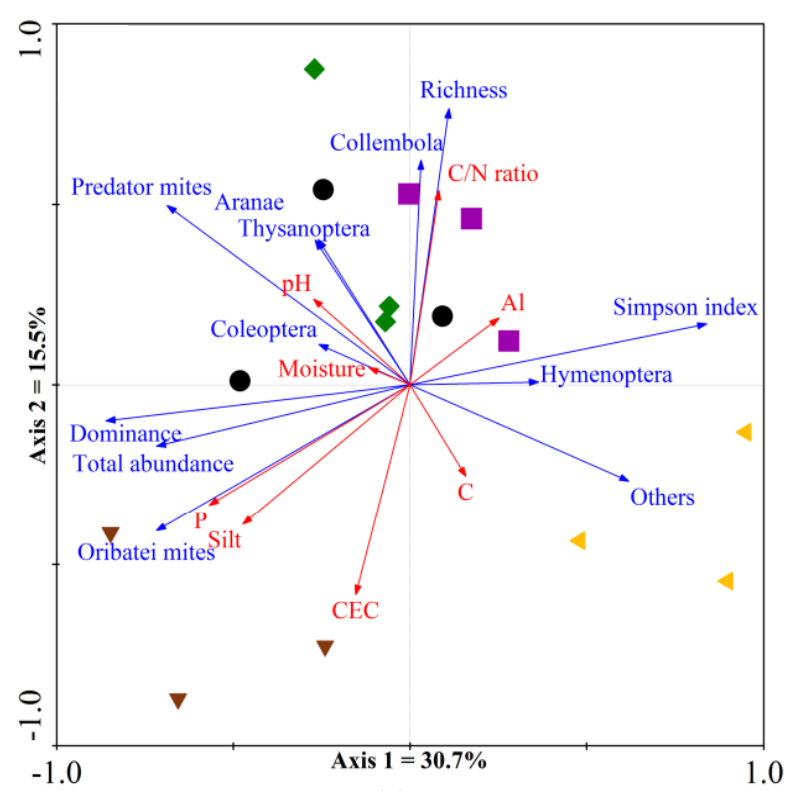

(a) positively with the abundance of "other" invertebrates (sum of Protura, Dipera larvae, Heteroptera, Chilopoda, Blattodea and Diplura), Thysanoptera and $\mathrm{Al}$; (3) EU correlated with C content, Collembola and total abundance and richness; (4) overlapping ICL and ICLF plots, associated with Aranae, mites, dominance, Coleoptera and soil moisture (Fig. 3b).

Therefore, some of the clusters found in winter were confirmed, although in the present case EU formed an isolated cluster. ICL and ICLF formed a single cluster, proving that integrated production systems under no-tillage can affect soil mesofauna abundance and diversity, favoring some groups, such as mites (predators and Oribatei) and spiders.

Positive relationships between abundance of mites and magnesium and soil moisture were observed, while total mesofauna abundance and richness were positively correlated with total soil carbon content (Table 5). It is possible that in autumn, when rainfall

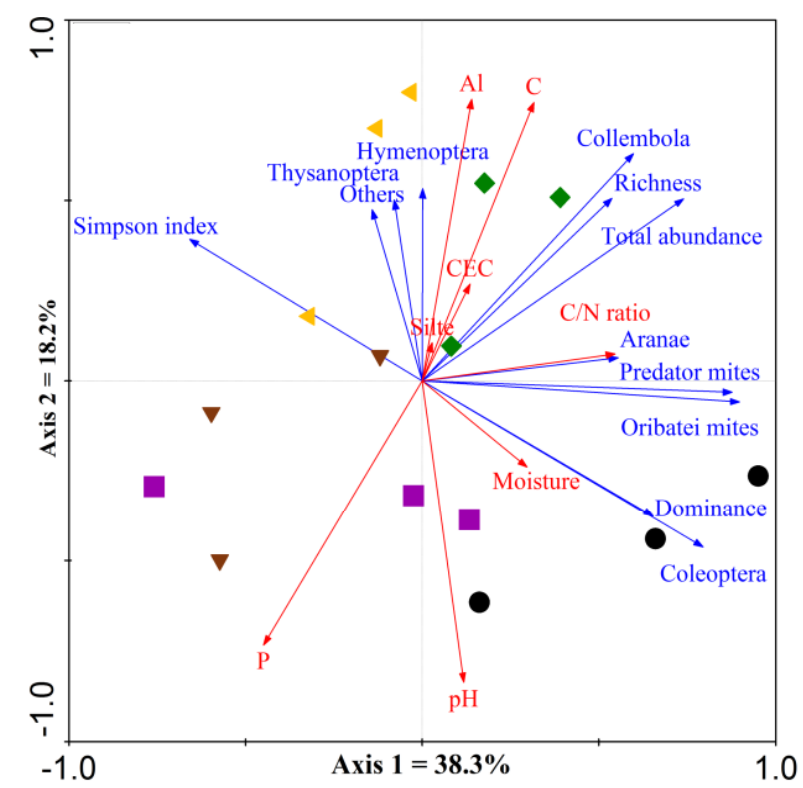

(b)

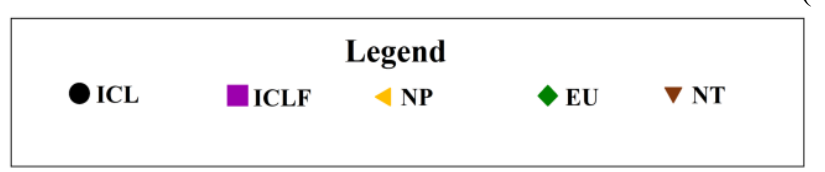

Fig. 3 Redundancy analysis of soil mesofauna abundance (blue arrows) and physical-chemistry soil properties (red arrows) in ICL, ICLF, NP, EU and NT systems.

Means of three plots sampled in winter (a) and autumn (b). 
is higher than winter, the soil remains more humid favoring mite reproduction and development, since they were more abundant in the first $10 \mathrm{~cm}$ of the soil [21]. On the other hand, higher amounts of mineral nutrients and carbon favor soil fauna abundance and richness, since organic carbon is the main energy source for soil organism development [42].

\subsection{General Considerations}

Overall, 15 mesofauna orders were identified, but richness in the different land use systems varied in 9-13 orders. Mean richness did not differ significantly between land use systems, but the Simpson index was higher in NP and lower in NT. Total richness was higher in autumn than that in winter in all the land uses (except NP, where nine groups were found), and followed the descending order EU $>$ ICL $>$ NT $=$ ICLF $>$ NP.

All the evaluated land use systems had higher Oribatei density than of predatory mites, especially in NT in the winter (Table 3). Oribatei mites indicate more stable conditions, since they colonize systems when equilibrium is obtained. These invertebrates have long life spans, low dispersion ability, high survival rates, high investment in defense and other competition mechanisms and constant density from generation to generation. On the other hand, predatory mites prepare the ecosystem for the establishment of more complex organisms. Frequently, predatory mites indicate disturbed and regenerating environments because of their high dispersion power, high mortality, high fertility and variable density $[43,44]$.

Most of the significant correlations observed in winter were not confirmed in the autumn and vice versa (Tables 4 and 5). These indicate that there were other factors, besides physical and chemical soil properties, influencing soil mesofauna abundance and diversity. For instance, it is known that soil microbial abundance and diversity, many times driven by plants, can determine soil invertebrate community composition, since many microbes actively mineralize nutrients to the soil solution that can be readily available to plants and soil mesofauna [36].

This study clearly showed how different soil properties and sampling season can influence soil mesofauna abundance and richness in management systems in the region of native grasslands of the uplands of Paraná state. The results also showed how management can influence these attributes. Studies evaluating interactions between soil fauna and soil attributes in Brazilian soils are scarce. And these organisms can be used to indicate soil quality and can be more responsive to changes than chemical and physical soil attributes [45], so more effort is needed in order to understand how soil attributes influence soil fauna populations in Brazilian ecosystems, particularly considering the diversity and potential richness of these ecosystems in the country.

Table 4 Significant Pearson correlation coefficients $(P<0.05)$ between physical-chemical soil attributes and the abundance of soil mesofauna groups in the winter sampling.

\begin{tabular}{lllllllllllllll}
\hline Groups & $\mathrm{pH}$ & $\mathrm{H}+\mathrm{Al}$ & $\mathrm{Ca}$ & $\mathrm{Mg}$ & $\mathrm{K}$ & $\mathrm{Na}$ & $\mathrm{SB}$ & $\mathrm{V} \%$ & $\mathrm{P}$ & $\mathrm{C}$ & $\mathrm{C} / \mathrm{N}$ & $\mathrm{N}$ & Sand & Silt \\
\hline Oribatei mites & - & - & - & - & 0.80 & - & - & - & 0.60 & - & -0.63 & 0.61 & -0.63 & 0.65 \\
Predator mites & - & - & - & - & - & 0.63 & - & - & - & - & - & - & - & - \\
Total mites & - & - & - & - & 0.74 & - & - & - & 0.56 & - & -0.57 & 0.59 & -0.66 & 0.67 \\
\hline Collembola & 0.59 & -0.52 & - & - & - & - & - & - & - & -0.55 & - & - & 0.56 & - \\
Aranae & - & - & - & - & - & - & - & - & - & - & 0.54 & - & - & - \\
Coleoptera larve & 0.53 & - & 0.63 & 0.78 & - & - & 0.67 & 0.57 & - & - & - & - & - & - \\
Protura & - & - & - & - & - & - & - & - & - & 0.52 & - & - & - & - \\
Diptera larve & - & - & - & - & 0.69 & - & - & - & - & - & -0.55 & 0.63 & -0.57 & 0.68 \\
Chilopoda & - & 0.54 & - & - & - & 0.73 & - & - & - & - & - & - & - & - \\
\hline Total abundance & - & - & - & - & 0.74 & - & - & - & 0.65 & - & -0.60 & - & -0.52 & 0.58 \\
\hline
\end{tabular}

-: no significant correlations. 
Table 5 Significant Pearson correlation coefficients $(P<0.05)$ between physical-chemical soil attributes and the abundance of soil mesofauna groups in the autumn sampling.

\begin{tabular}{|c|c|c|c|c|c|c|c|c|c|c|c|c|c|c|c|}
\hline Groups & $\mathrm{pH}$ & $\mathrm{Al}$ & $\mathrm{H}+\mathrm{Al}$ & $\mathrm{Ca}$ & $\mathrm{Mg}$ & $\mathrm{K}$ & $\mathrm{Na}$ & SB & $\mathrm{V} \%$ & $\mathrm{~m} \%$ & $\mathrm{P}$ & $\mathrm{C}$ & $\mathrm{C} / \mathrm{N}$ & Clay & Moisture \\
\hline Oribatei mites & - & - & - & - & 0.58 & - & - & - & - & - & - & - & - & - & 0.56 \\
\hline Predator mites & - & - & - & - & 0.55 & - & - & - & - & - & - & - & - & - & 0.54 \\
\hline Total mites & - & - & - & - & 0.58 & - & - & - & - & - & - & - & - & - & 0.56 \\
\hline Collembola & -0.59 & 0.85 & 0.67 & -0.65 & - & -0.61 & 0.81 & -0.62 & -0.69 & 0.83 & -0.77 & 0.70 & - & - & - \\
\hline Coleoptera adult & - & - & - & - & - & - & 0.60 & - & - & - & - & - & - & - & - \\
\hline Coleoptera larve & 0.72 & -0.53 & -0.69 & 0.65 & 0.75 & - & - & 0.67 & 0.69 & - & - & - & - & - & - \\
\hline Total Coleoptera & 0.53 & - & - & - & - & - & - & - & - & - & - & - & - & - & - \\
\hline Thysanoptera & -0.60 & - & - & - & - & - & - & - & - & - & - & - & - & - & - \\
\hline Chilopoda & - & 0.72 & - & -0.63 & -0.65 & -0.58 & 0.67 & -0.64 & -0.61 & 0.85 & - & - & 0.54 & 0.59 & - \\
\hline Total abundance & - & - & - & - & - & - & - & - & - & - & -0.53 & 0.52 & - & - & - \\
\hline Richness & - & - & - & - & - & - & 0.60 & - & - & - & -0.56 & 0.55 & - & - & - \\
\hline Simpson index & - & - & - & - & -0.53 & - & - & - & - & - & - & - & - & - & - \\
\hline
\end{tabular}

-: no significant correlations.

The present study also showed how mesofauna density can be highly variable within the same ecosystem and among ecosystems. This common variability in soil fauna data may be due not only to several intrinsic soil factors (physical, chemical or biological), but also to management and abiotic characteristics, such as climate and collection site [46]. To minimize these factors, it is recommended that sampling of the animals should be in sufficient number of replicate samples (preferably $>10$ per ecosystem) and all on the same date evaluated in different ecosystems (to avoid effects of abiotic extremes, such as large rainfalls, flood or frost). Furthermore, soil and mesofauna samples should be taken from the same collection point in a similar number in order to make correlations using all independent samples.

\section{Conclusions}

The present paper presents the first published results on soil mesofauna in integrated production systems in Brazil. It was found that these systems support a large and diverse mesofauna community that is highly regulated by soil moisture. However, other important factors governing the density and diversity of soil mesofauna are the use of trees in agroecosystems, the adoption of no-tillage practices (reducing soil disturbance) and the intrinsic or managed soil physical and chemical properties, such as $\mathrm{C} / \mathrm{N}$ ratio, $\mathrm{pH}, \mathrm{Al}, \mathrm{P}$ and $\mathrm{C}$ contents, as well the use of insecticides, herbicides and fungicides. Few studies in Brazil have evaluated simultaneously soil properties and mesofauna communities, although correlations increase the understanding of soil fauna and their ecology in natural and managed ecosystems. It was found in this study that many of the correlations obtained in the winter did not remain in autumn and vice versa, indicating that there are more factors, beyond the physical and chemical soil attributes, governing the mesofauna distribution in the soil. Thus, more future studies including soil mesofauna, physical-chemical soil attributes and soil microorganisms were recommended.

\section{References}

[1] Karlen, D. L., Mausbach, M. J., Doran, J. W., Cline, R. G., Harris, R. F., and Schuman, G. E. 1997. "Soil Quality: A Concept, Definition and Framework for Evaluation." Soil Sci. Soc. Am. J. 61: 4-10.

[2] Wander, M. M., and Drinkwater, L. E. 2000. "Fostering Soil Stewardship through Soil Quality Assessment." Appl. Soil Ecol. 15 (1): 61-73.

[3] Doran, J. W., and Zeiss, M. R. 2000. "Soil Health and Sustainability: Managing the Biotic Component of Soil Quality.” Appl. Soil Ecol. 15 (1): 3-11.

[4] Parron, L. M., Garcia, J. R., Oliveira, E. B., Brown, G. G., and Prado, R. B. 2015. Environmental Services in 
Agricultural and Forest Systems of the Mata Atlântica Biome. Brasília, DF: EMBRAPA. (in Portuguese)

[5] Barbercheck, M. E., Neher, D. A., Anas, O., El-Allaf, S. M., and Weicht, T. R. 2009. "Response of Soil Invertebrates across Three Resource Regions in North Carolina." Environ. Monit. Assess. 152: 283-98.

[6] Cezar, R. M., Vezzani, F. M., Schwiderke, F. M., Gaiad, S., Brown, G. G., Seoane, C. E. S., and Froufe, L. C. M. 2015. "Soil Biological Properties in Multistrata Successional Agroforestry Systems and in Natural Regeneration.” Agrofor. Syst. 89 (6): 1035-47.

[7] Lavelle, P. 1997. "Faunal Activities and Soil Processes: Adaptive Strategies that Determine Ecosystem Function." Adv. Ecol. Res. 27: 93-132.

[8] Franklin, E., Magnusson, E., and Luizão, F. J. 2005. "Relative Effects of Biotic and Abiotic Factors on the Composition of Soil Invertebrates Communities in an Amazonian Savannah.” Appl. Soil Ecol. 29 (3): 259-73.

[9] Loranger, G., Franços-Ponge, J., Blanchart, E., and Lavelle, P. 1999. "Influence of Agricultural Practices on Arthropod Communities in a Vertisol (Martinique)." Eur. J. Soil Biol. 34 (4): 157-65.

[10] Franklin, E. N., Morais, J. W., and Santos, E. M. R. 2001. "Density and Biomass of Acari and Collembola in Primary Forest, Secondary Regrowth and Polycultures in the Central Amazonia." Andrias 15: 141-53.

[11] Macedo, M. C. M. 2009. "Crop and Livestock Integration: The State of the Art and the Near Future." Rev. Bras. Zootec. 38: 133-46. (in Portuguese)

[12] Balbino, L. C., Barcelos, A. O., and Stone, L. F. 2011. Referential Framework: Crop and Livestock Forest Integration. Brasília, DF: EMBRAPA. (in Portuguese)

[13] Portilho, I. I. R., Crepaldi, R. A., Borges, C. D., Silva, R. F., Salton, J. C., and Mercante, F. M. 2011. "Invertebrate Fauna and Physical and Chemical Attributes of Soil under Integrated Crop-Livestock Systems." Pesq. Agropec. Bras. 46 (10): 1310-20. (in Portuguese)

[14] IAPAR. 1978. Basic Climate Maps of Paraná State. PR, BR: Fundação Instituto Agronômico do Paraná. (in Portuguese)

[15] EMBRAPA. 2011. Manual of Soil Analysis Methods. RJ, BR: EMBRAPA. (in Portuguese)

[16] Nelson, D. W., and Sommers, L. E. 1982. "Total Carbon, Organic Carbon and Organic Matter." In Methods of Soil Analysis. Part 2: Chemical and Microbiological Properties, edited by Page, A. L., Miller, R. H., and Keeney, D. R. Madison: ASA and SSSA, 539-79.

[17] Magurran, A. 2004. Measuring Biological Diversity. Oxford, UK: Blackwell Science.

[18] Ter Braak, C. J. F., and Smilauer, P. 2002. Canoco Reference Manual and Cano Draw for Windows User's
Guide: Software for Canonical Community Ordination. Version 4.5. Ithaca, NY: Microcomputer Power.

[19] Melo, M. S., Moro, R. S., and Guimarães, G. B. 2007. Natural Patrimony of Campos Gerais. Ponta Grossa, PR: UEPG. (in Portuguese)

[20] Moreno, J. L., Bastida, F., Ondoño, S., García, C., Andrés-Abellán, M., and López-Serrano, F. R. 2017. “Agro-forestry Management of Paulownia Plantations and Their Impact on Soil Biological Quality: The Effects of Fertilization and Irrigation Treatments." Appl. Soil Ecol. 117: 46-56.

[21] Schwinning, S., and Sala, O. E. 2004. "Hierarchy of Responses to Resource Pulses in Arid and Semi-arid Ecosystems." Oecologia 141 (2): 211-20.

[22] Manhães, C. M. C., Gama-Rodrigues, E. F., Moço, M. K. S., and Gama-Rodrigues, A. C. 2013. "Meso- and Macro-fauna in the Soil and Litter of Leguminous Trees in a Degraded Pastures in Brazil." Agrofor. Syst. 87 (5): 993-1004.

[23] Marchão, R. L., Balbino, L. C., Becquer, T., Celini, L., Lavelle, P., and Vilela, L. 2009. "Soil Macrofauna under Integrated Crop-Livestock Systems in a Brazilian Cerrado Ferralsol.” Pesq. Agropec. Bras. 44 (8): 1011-20.

[24] Costa, P. M. O., Araújo, M. A. G., Souza-Motta, C. M., and Malosso, E. 2017. "Dynamics of Leaf Litter and Soil Respiration in a Complex Multistrata Agroforestry System, Pernambuco, Brazil.” Envirom. Dev. Sustain. 19 (4): 1189-203.

[25] Gupta, V. V. S. R. 1994. "The Impact and Crop Management Practices on the Dynamics of Soil Microfauna and Mesofauna." In Soil Biota: Management in Sustainable Farming Systems, edited by Pankhurst, C. E., Doube, B. M., Gupta, V. V. S. R., and Grace, P. R. Melbourne: CSIRO, 107-24.

[26] Lins, V. S., Santos, H. R., and Gonçalves, M. C. 2007. "The Effect of the Glyphosate, 2,4-D, Atrazine and Nicosulfuron Herbicides upon the Edaphic collembola (Arthropoda: Ellipura) in a No Tillage System.” Neotrop. Entomol. 36 (2): 261-7.

[27] Polierrer, M. M., Langel, R., Korner, C., Maraum, M., and Scheu, S. 2007. "The Underestimated Importance of Belowground Carbon Input for Forest Soil Animal Food Webs." Ecol. Lett. 10 (8): 729-36.

[28] Paoletti, M. G., Bater, J. E., Favretto, M. R., Purrington, F. F., and Stinner, B. R. 1991. "Invertebrates as Bioindicators of Soil Use.” Agri. Ecosyst. Environ. 34: 341-62.

[29] Buch, A. C., Correia, M. E. F., Teixeira, D. C., and Silva-Filho, E. V. 2015. "Characterization of Soil Fauna under the Influence of Mercury Atmospheric Deposition in Atlantic Forest, Rio de Janeiro, Brazil." J. Environ. Sci. 32: 217-27.

[30] Moço, M. K. S., Gama-Rodrigues, E. F., 


\section{Soil Invertebrates in Different Land Use Systems: How Integrated Production Systems and Seasonality Affect Soil Mesofauna Communities}

Gama-Rodrigues, A. C., and Correia, M. E. F. 2005. "Characterization of Soil Fauna in Different Vegetation Covers in the Northern Fluminense Region (RJ)." Rev. Bras. Ciênc. Solo 29 (4): 555-64. (in Portuguese)

[31] Nogueira, V. L. R., Rocha, L. L., Colares, G. M., Angelim, A. L., Normando, L. R. O., Cantão, M. E., Andreote, F. D., and Melo, V. M. M. 2015. "Microbiomes and Potential Metabolic Pathways of Pristine and Anthropized Brazilian Mangroves." Regional Studies in Marine Science 2: 56-64.

[32] Benito, N. P., Brossard, M., Pasini, A., Guimarães, M. F., and Bobillier, B. 2004. "Transformations of Soil Macroinvertebrate Populations after Native Vegetation Conversion to Pasture Cultivation (Brazilian Cerrado)." Eur. J. Soil Biol. 40: 147-54.

[33] Constantino, R. 2005. "Diversity and Endemism Patterns of Termites in Cerrado." In Cerrado: Ecology, Biodiversity and Conservation, edited by Scariot, A., Souza-Silva, J. C., and Felfili, J. M. Brasília, DF: Ministério do Meio Ambiente, 319-33. (in Portuguese)

[34] Rosa, M. G., Filho, O. K., Bartz, M. L. C., Mafra, A. L., Sousa, J. P. F. A., and Baretta, D. 2015. "Soil Macrofauna and Physical and Chemical Properties under Soil Management Systems in the Santa Catarina Highlands, Brazil." Rev. Bras. Ciênc. Solo 39 (6): 1544-53. (in Portuguese)

[35] Peña-Peña, K., and Irmler, U. 2016. "Moisture Seasonality, Soil Fauna, Litter Quality and Land Use as Drivers of Decomposition in Cerrado Soils in SE-Mato Grosso, Brazil.” Appl. Soil Ecol. 107: 124-33.

[36] Andreote, F. D., Gumiere, T., and Durrer, A. 2014. "Exploring Interactions of Plant Microbiomes." Sci. Agric. 71 (6): 528-39.

[37] Corrêa Neto, T. A., Pereira, M. G., Correa, M. E. F., and Anjos, L. H. C. 2001. "Litter Deposition and Soil Mesofauna of a Secondary Forest and Eucalyptus Plantation." Floresta e Ambiente. 8 (1): 70-5. (in
Portuguese)

[38] Eckardt, D. P., Redin, M., Jacques, R. J. S., Lorensini, F., Santos, M. L., Weiler, D. A., and Antoniolli, Z. I. 2016. "Mineralization and Efficiency Index of Nitrogen in Cattle Manure Fertilizers on the Soil." Ciência Rural 46 (3): 472-7.

[39] Lutinski, J. A., Garcia, F. R. M., Lutinski, C. J., and Iop, S. 2008. "Ants Diversity in Chapecó National Forest in Santa Catarina State, Brazil.” Ciência Rural 38 (7): 1810-6. (in Portuguese).

[40] Pass, G., and Szucsich, N. U. 2011. "100 Years of Research on the Protura: Many Secrets Still Retained." Soil Organisms 83 (3): 309-34.

[41] Malmstrom, A., and Persson, T. 2011. "Response of Collembola and Protura to Tree Girdling: Some Support for Ectomycorrhizal Feeding." Soil Organisms 83 (2): 279-85.

[42] Brandani, C. B., and Santos, D. G. 2016. "Carbon Transformations in Soil." In Soil Microbiology, edited by Cardoso, E. J. B. N., and Andreote, F. D. Piracicaba, SP: ESALQ, 81-96. (in Portuguese)

[43] Greenslade, P. J. M. 1983. "Adversity Selection and the Habitat Templet.” Am. Nat. 122 (3): 352-65.

[44] Sinervo, B., Svensson, E., and Comedant, T. 2000. "Density Cycles and an Offspring Quantity and Quality Game Driven by Natural Selection." Nature 406: 985-8.

[45] Cardoso, E. J. B. N., Vasconcellos, R. F. L., Bini, D., Miyauchi, M. Y. H., Santos, C. A., Alves, P. R. L., Monteiro, P. A., Nakatani, A. S., Pereira, J. M., and Nogueira, M. A. 2013. "Soil Health: Looking for Suitable Indicators-What Should Be Considered to Assess the Effects of Use and Management on Soil Health?" Sci. Agric. 70 (4): 274-89.

[46] Moreira, F. M. S., Huising, E., and Bignell, D. E. 2010. Manual of Tropical Soil Biology: Sampling and Characterization of Biodiversity. Lavras, BR: Editora UFLA. (in Portuguese) 